OPEN ACCESS

Edited by:

Christos Theleritis,

National and Kapodistrian University

of Athens, Greece

Reviewed by:

Kostas Siarkos,

National and Kapodistrian University of Athens, Greece

Lucia Sideli,

University of Cagliari, Italy

*Correspondence:

Hervita Diatri

hervita94@yahoo.com

Specialty section: This article was submitted to

Public Mental Health, a section of the journal

Frontiers in Psychiatry

Received: 28 November 2020 Accepted: 15 February 2021

Published: 10 March 2021

Citation: Anindyajati G, Wiguna T, Murtani BJ, Christian H, Wigantara NA, Putra AA,

Hanafi E, Minayati K, Ismail RI,

Kaligis F, Savitri Al, Uiterwaal CSPM and Diatri $H$ (2021) Anxiety and lts Associated Factors During the Initial Phase of the COVID-19 Pandemic in Indonesia.

Front. Psychiatry 12:634585 doi: 10.3389/fpsyt.2021.634585

\section{Anxiety and Its Associated Factors During the Initial Phase of the COVID-19 Pandemic in Indonesia}

\author{
Gina Anindyajati ${ }^{1}$, Tjhin Wiguna ${ }^{1}$, Belinda Julivia Murtani ${ }^{1}$, Hans Christian ${ }^{1}$, \\ Ngurah Agung Wigantara ${ }^{1}$, Anggi Aviandri Putra ${ }^{1}$, Enjeline Hanafi ${ }^{1}$, Kusuma Minayati ${ }^{1}$, \\ Raden Irawati Ismail ${ }^{1}$, Fransiska Kaligis ${ }^{1}$, Ary I. Savitri ${ }^{2}$, Cuno S. P. M. Uiterwaal ${ }^{3}$ and \\ Hervita Diatri ${ }^{1 *}$ \\ ${ }^{1}$ Department of Psychiatry, Faculty of Medicine, Universitas Indonesia-Cipto Mangunkusumo Hospital, Jakarta, Indonesia, \\ ${ }^{2}$ The Center for Clinical Epidemiology and Evidence-Based Medicine Faculty of Medicine, Universitas Indonesia-Cipto

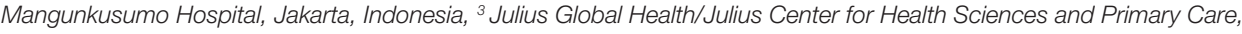 \\ University Medical Center Utrecht, Utrecht, Netherlands
}

Introduction: Coronavirus disease 2019 (COVID-19) is caused by a novel coronavirus which has not been identified previously in humans. The disease leads to respiratory problems, systemic disorders, and death. To stop the virus transmission, physical distancing was strongly implemented, including working and school from home (WFH \& SFH). The limitation altered daily routines and needs advanced to adapt. Many have felt uncomfortable and this could have triggered anxiety symptoms. This study aimed to evaluate the proportion of significant anxiety symptoms and its association with COVID-19-related situations in an Indonesian context during the initial months of the pandemic.

Methods: An online community survey was distributed through social media and communication platforms, mainly WhatsApp, targeting people $>18$ years old in Indonesia. Anxiety symptoms were assessed using Generalized Anxiety Disorder-7 (Indonesian Version). Demographical data and information on social situation related to the COVID-19 pandemic were collected. The proportion of clinically significant anxiety symptoms was calculated and the association with demographic and social factors was assessed using chi square test $\left(\chi^{2}\right)$ and logistic regression for multivariate analysis.

Results: Out of 1215 subjects that completed the survey, 20.2\% $(n=245)$ exhibited significant anxiety symptoms. Several factors, such as age (AOR $=0.933 \mathrm{Cl} 95 \%$ $=0.907-0.96)$, $\operatorname{sex}(\mathrm{AOR}=1.612 \mathrm{Cl} 95 \%=1.097-2.369$ ), medical workers (AOR $=0.209 \mathrm{Cl} 95 \%=0.061-0.721)$, suspected case of COVID-19 (AOR = 1.786 $\mathrm{Cl} 95 \%=1.001-3.186)$, satisfaction level of family support $(\mathrm{AOR}=3.052 \mathrm{Cl}$ $95 \%=1.883-4.946)$, and satisfaction level of co-workers ( $A O R=2.523 \mathrm{Cl} 95 \%$ =1.395-4.562), were associated with anxiety.

Conclusion: One out of five Indonesian people could have suffered from anxiety during the COVID-19 pandemic. The riskiest group being young females, people who had suspected cases of COVID-19, and those with less satisfying social support. 
Nevertheless, health workers were found to have a lesser risk of developing anxiety. Accessible information and healthcare, social connection, supportive environment, and mental health surveillance are important to prevent bigger psychiatric problems post-pandemic.

Keywords: anxiety, COVID-19 pandemic, Indonesian, mental health surveillance, psychosocial support

\section{INTRODUCTION}

Coronaviruses are a group of viruses with a single-stranded RNA structure. Some of the subtypes are known to affect humans, most of which cause mild infections in the upper respiratory tract of immunocompetent individuals (1-3). Some notable once-novel variants of these viruses have caused several outbreaks on a larger scale, such as the severe acute respiratory syndrome (SARS) outbreak in 2002 and the Middle East respiratory syndrome (MERS) in $2012(2,3)$. The common signs and symptoms of coronavirus disease 2019 (COVID-19) infection include acute respiratory symptoms, such as fever, cough, and dyspnea. The disease can lead to pneumonia, acute respiratory distress, acute kidney injury, and even death (4). At the end of January 2020, WHO declared COVID-19 as a public health emergency (5). The virus infection has spread to over 182 countries including Indonesia. The global devastation has well-overtaken the SARS epidemic in 2003, which affected 26 countries and caused 800 deaths worldwide (6). The rising global case numbers are the unprecedented health event of this century. The general public is under increasing strain due to the constant updates from health authorities. Moreover, almost unlimited news coverage from mass media has already been shown to be related to and amplify the level of anxiety across the viewership $(7,8)$.

In order to minimize the coronavirus infection rates, governments and health authorities of countries worldwide, including Indonesia, have implemented large-scale social restriction measures for various communal activities, including changes in the systems of labor and school from home largely starting as of April 2020 (9). Short-term social restriction might not be a significant problem for the majority of people (10); however, as social beings, extended social restriction may be expected to cause mental health problems. Reflecting on the Indonesian context, where people commonly have a close relationship with extended family and peers, social restriction and the abrupt change to remote working and home-based learning, especially for extended periods, will potentially affect mental well-being.

The mental problems that might be found during a pandemic can be summarized into: (1) stress and anxiety for self and family health, e.g., being transmitted to or transmitting the disease to family or society $(11,12)$; (2) sleep and eating disorders; (3) attention disturbance; and (4) increased substance use. Stress is a feeling of emotional and physical tension which arises from any event that affects homeostasis (13). While fear of the unknown may cause anxiety, it is a natural bodily response to stress. Acute stress, depression, and anxiety have been rising significantly during the COVID-19 lockdown, and will likely increase when prolonged (12). Therefore, it is crucial to study how alarming the anxiety is in the population, especially in relation to daily life functions (13).

Based on a study in Basque, Spain, anxiety was experienced by all ages, although younger people showed greater stress compared to older people (12). Anxiety is believed to be exacerbated by any exposure of the public to false information that leads to misinterpretations and developing negative thoughts and insecurity $(8,14)$. These conditions also likely threaten many other groups of people including medical workers (15). Increasing risks to the mental health of medical staff have been reported previously during infectious disease pandemics; PTSD increased by $20 \%$ during the SARS epidemic in $2003(16,17)$.

Indonesia Basic Health Research 2018 data showed that about $9.8 \%$ of the population has mental and emotional health problems (18). The current COVID-19 pandemic may further raise the proportion of the population that experiences emotional problems. The aim of our study was to evaluate the relationship between anxiety symptoms and the COVID-19 pandemic situation by estimating the current population prevalence of such symptoms. We hypothesized that anxiety level during the COVID-19 pandemic was higher compared to prevalence before the pandemic. In addition, we believed that several factors, for example, socio-demographic characteristics, access to health information, social restriction practice, status of COVID19 infection, and social support, were related to anxiety. The result of this study could help establish baseline data on mental health in the general population nationwide, and be used as a reference to develop public policy for psychosocial support during a pandemic.

\section{METHODS}

\section{Design}

The current study was part of a larger community survey evaluating anxiety during the COVID-19 pandemic in Indonesia. This cross-sectional study was conducted involving the adult Indonesian population from April to May 2020, which was the first and second period of large-scale social restriction implementation. Data were collected through an online questionnaire using the SurveyMonkey program. The survey was distributed through various social media and communication platforms, including WhatsApp groups and personal accounts on Instagram, Twitter, and Facebook as the most commonly used social media by the public (19). Each respondent was asked to give their informed consent before filling out the questionnaire, of which a total of 1,215 
adults participated and completed. The protocol of this study was reviewed and approved by the Medical Research Ethics Committee of the Faculty of Medicine Universitas Indonesia (KET-375/UN2.F1/ETIK/PPM.00.02/2020).

\section{Measurements}

Data on respondents' demographic information, social situation related to COVID-19, and anxiety level were collected. Demographic information included age, gender, educational level, occupation, place of current residence, and socio-economic status. Education was classified into lower (elementary/junior/high school) and higher (bachelor/master/doctoral) levels. Socio-economic status was classified into low to lower-middle income and uppermiddle to high income groups according to the gross national income classification by the World Bank. All the respondents were also asked about their implementation of working from home and social restriction policy (physical distancing, minimizing outdoor activity, avoiding group gatherings) during the pandemic, current health status of the respondents and their families regarding COVID-19, and their access to related information, such as physical and mental health guidance. The information sources were differentiated into online media, offline media, and direct information from family or friends.

Health status regarding COVID-19 was classified according to the World Health Organization case definition as follows: healthy individual, suspect case, probable case, and confirmed case. A suspect case of COVID-19 applies to individuals who (1) experience acute respiratory illness (fever and at least one respiratory symptoms); (2) have traveled to, or have a residency history in a local transmission area or contact history with confirmed or probable cases during the last 14 days before symptoms onset. A probable case is a suspect case who has obtained inconclusive laboratory test results. A confirmed case is defined as a person who has a confirmed laboratory test result of a COVID-19 infection.

Several questions were aimed to investigate the respondents' behavior changes during the pandemic, along with satisfaction level toward support from family, friends, and colleagues using a single question for each item. Behavior changes were measured on a yes or no scale. Satisfaction toward support system was classified into satisfied and not satisfied. Family members in an Indonesian context are considered not restricted to the nuclear family (a pair of adults and their socially recognized children, regarded as a basic social unit) but also include extended family members, such as grandparents (20). The respondents were asked to describe all of these variables according to their experiences in the last 4 weeks before completing this questionnaire.

The level of anxiety was assessed using the Indonesian version of Generalized Anxiety Disorder-7 (GAD-7). It is a self-report anxiety screening tool for adults (aged 18-95 years old) which was originally developed by Spitzer et al. (21). This instrument was translated into the Indonesian language by Budikayanti et al. (22) and exhibited good validity and reliability (Cronbach's $\alpha$ $=0.867$ ) (22). The scale consists of seven items evaluating how often the respondents were bothered by anxiety symptoms in the last 2 weeks. It is scored on a 4 -point Likert scale $(0=$ not at all,
$1=$ several days, $2=$ more than half the days, $3=$ nearly every day). A total score of 8 or greater is considered as corresponding to clinically significant anxiety (23).

\section{Statistical Analyses}

Prevalence of anxiety disorders was estimated based on the proportion of respondents with clinically significant anxiety. Furthermore, we evaluated if socio-demographic characteristics, access to health information, social restriction practice, health status (COVID-19 infection), and social support had associations with the occurrence of anxiety. Univariate logistic regression was first performed to evaluate the unadjusted association between each factor and anxiety disorder. The statistically significant factors $(p<0.05)$ from the univariable analyses were then evaluated using a multivariate logistic regression. Data analysis was performed using SPSS IBM version 25.

\section{RESULTS}

\section{Characteristics of Participants}

Of the 1,215 respondents included in this study, $245(20.2 \%$, CI 95\% 17.9-22.5) exhibited clinically significant anxiety. The general characteristics of the respondents are shown in Table 1. The median age of respondents was $29(\min -\max =18-88)$ years old. Two thirds of the respondents were female $(n=884$, $72.8 \%)$ and 1,026 (84.4\%) had finished a higher educational level. Respondents mainly came from the western part of Indonesia, including those who lived in DKI Jakarta, West Java, and Banten, and belonged to the upper-middle to high income socioeconomic level.

Sixty percent of the respondents $(n=739)$ were working from home at the time of the survey and most of them were implementing the social restriction policy. A majority of respondents had access to physical health information regarding COVID-19 ( $n=1,126,92.7 \%)$, yet only half of them $(n=640,52.7 \%)$ received related mental health information. Most respondents reported to be healthy $(n=1,132,93.1 \%)$ and only a few $(n=38,3.1 \%)$ had family members with suspected cases of COVID-19. The survey showed that respondents felt satisfied with the support they received from family, friends, and colleagues (Table 2).

\section{Factors Associated With Anxiety During the COVID-19 Pandemic in Indonesia}

In the univariate analysis, age was statistically significantly related to anxiety. The clinically significant anxiety group had a lower median of age compared to the not-clinically significant anxiety group. Furthermore, several factors, such as sex, level of education, occupation, level of income, and marital status, were found to be related to anxiety. Satisfaction level of support from family, friends, and co-workers was also found to have an association with anxiety (Table 3).

Multivariate analysis (Table 3) showed that age was related to clinically significant anxiety, in which older age was found to have a lower risk of developing clinically significant anxiety. In addition, health workers had an almost five times lower chance of developing clinically significant anxiety when compared 
TABLE 1 | General characteristics of respondents.

\begin{tabular}{|c|c|c|c|}
\hline & & $n=1,215$ & Percentage (\%) \\
\hline \multicolumn{2}{|c|}{ Age (Median; Min-Max) } & $29(18-88)$ & \\
\hline \multirow[t]{2}{*}{ Sex } & Female & 884 & 72.76 \\
\hline & Male & 331 & 27.24 \\
\hline \multirow[t]{2}{*}{ Educational Level } & $\begin{array}{l}\text { Elementary/Junior/Senior } \\
\text { High School }\end{array}$ & 189 & 15.56 \\
\hline & Bachelor/Master/Doctoral & 1,026 & 84.44 \\
\hline \multirow[t]{8}{*}{ Occupation } & Private Employee & 366 & 30.12 \\
\hline & Medical workers & 284 & 23.37 \\
\hline & Students & 194 & 15.97 \\
\hline & Housewife & 104 & 8.56 \\
\hline & Public Employee & 97 & 7.98 \\
\hline & Teacher & 77 & 6.34 \\
\hline & Entrepreneur & 76 & 6.26 \\
\hline & Unemployed & 17 & 1.40 \\
\hline \multirow[t]{2}{*}{ Level of income } & $\begin{array}{l}\text { Low to lower middle } \\
\text { income ( } \leq \$ 3,995 / \text { year })\end{array}$ & 443 & 36.46 \\
\hline & $\begin{array}{l}\text { Upper middle to high } \\
\text { income (>\$3,995/year) }\end{array}$ & 772 & 63.54 \\
\hline \multirow[t]{3}{*}{ Marital Status } & Single & 649 & 53.42 \\
\hline & Married & 534 & 43.95 \\
\hline & Widow/widower & 32 & 2.63 \\
\hline \multirow[t]{10}{*}{ Domicile } & DKI Jakarta & 432 & 35.56 \\
\hline & West Java & 249 & 20.49 \\
\hline & Banten & 131 & 10.78 \\
\hline & East Java & 85 & 7.00 \\
\hline & Central Java & 73 & 6.01 \\
\hline & Riau & 34 & 2.80 \\
\hline & South Sulawesi & 26 & 2.14 \\
\hline & Yogyakarta & 25 & 2.06 \\
\hline & Bali & 23 & 1.89 \\
\hline & Others & 138 & 11.36 \\
\hline
\end{tabular}

to those who were unemployed. However, female sex was independently related to the higher possibility of anxiety. A similar trend was seen for being a suspected case of COVID19. Furthermore, respondents who reported dissatisfaction toward family and co-workers' support had a three- and two-times higher chance of developing clinically significant anxiety, respectively.

\section{DISCUSSION}

This study showed that $20 \%$ of our respondents had clinically significant anxiety during the COVID-19 pandemic. Anxiety was more common among those who were female, attained a low educational level, were unmarried, and reported dissatisfaction toward family, friends, and co-workers' support. This was the first study involving nationwide respondents to examine anxiety level and its association with psychosocial factors among the adult population in Indonesia during the COVID-19 pandemic. This was also the first to report anxiety proportion in an Indonesian population.
TABLE 2 | Social situation related to COVID-19 in Indonesia.

\begin{tabular}{|c|c|c|c|}
\hline & & $n=1,215$ & $\begin{array}{c}\text { Percentage } \\
(\%)\end{array}$ \\
\hline \multirow{2}{*}{$\begin{array}{l}\text { Access to physical health } \\
\text { information about COVID-19 }\end{array}$} & Yes & 1,126 & 92.67 \\
\hline & No & 89 & 7.33 \\
\hline \multirow{2}{*}{$\begin{array}{l}\text { Access to mental health information } \\
\text { about COVID-19 }\end{array}$} & Yes & 640 & 52.67 \\
\hline & No & 575 & 47.33 \\
\hline \multirow[t]{2}{*}{ Working from home } & Yes & 739 & 60.82 \\
\hline & No & 476 & 39.18 \\
\hline \multirow[t]{2}{*}{ Practicing social restriction } & Yes & 1,181 & 97.20 \\
\hline & No & 34 & 2.80 \\
\hline \multirow[t]{2}{*}{ Being a suspect case of COVID-19 } & Yes & 83 & 6.83 \\
\hline & No & 1,132 & 93.17 \\
\hline \multirow{2}{*}{$\begin{array}{l}\text { Had family member with suspect } \\
\text { case of COVID-19 }\end{array}$} & Yes & 113 & 9.30 \\
\hline & No & 1,102 & 90.70 \\
\hline \multirow{2}{*}{$\begin{array}{l}\text { Applying behavior changes due to } \\
\text { COVID-19 pandemic }\end{array}$} & Yes & 1,140 & 93.83 \\
\hline & No & 75 & 6.17 \\
\hline \multirow[t]{2}{*}{ Satisfaction level of family support } & Not Satisfied & 106 & 8.72 \\
\hline & Satisfied & 1,109 & 91.28 \\
\hline \multirow[t]{2}{*}{ Satisfaction level of friends support } & Not Satisfied & 83 & 6.83 \\
\hline & Satisfied & 1,132 & 93.17 \\
\hline \multirow{2}{*}{$\begin{array}{l}\text { Satisfaction level of co-workers } \\
\text { support }\end{array}$} & Not Satisfied & 111 & 9.14 \\
\hline & Satisfied & 1,104 & 90.86 \\
\hline \multirow{2}{*}{$\begin{array}{l}\text { Clinically significant anxiety } \\
(\text { GAD score }>8)\end{array}$} & Yes & 245 & 20.16 \\
\hline & No & 970 & 79.84 \\
\hline
\end{tabular}

The study was conducted through an online survey that made it easy and convenient for respondents to participate. However, our study also had limitations due to restriction in eligibility criteria, and relying on respondent's willingness to participate in the survey may lead to selection bias. The majority of respondents were female, of younger age, completed higher education, and had an upper-middle to high socio-economic level; thus, they may not represent the whole Indonesian population. Based on the National Census of $2020,70 \%$ of the Indonesian population are of productive age (15-64 years old), with a balanced number of both females and males, and with only $10.2 \%$ who had completed higher education (24).

Similar findings were found in other online studies in Indonesia. The psychosocial aspect of the pandemic also had a majority of female respondents $(25,26)$, even though both sexes numbers are equal based on the latest national census (27). This study also did not validate the data collected based on certain standards, however our findings were similar with previous research $(8,28)$. The current study also did not investigate previous common mental disease or previous contact with mental health services. This may have resulted in an overestimation of anxiety prevalence in our study. Internet access provides massive exposure to COVID-19 information, from sources such as social media and online news portals, which may have consequently caused anxiety. Furthermore, a previous study showed that anxiety was more common in the younger 
TABLE 3 | Analysis of factors associated to anxiety.

\begin{tabular}{|c|c|c|c|c|c|c|c|c|c|c|c|}
\hline & & \multicolumn{2}{|c|}{$\begin{array}{l}\text { Clinically significant } \\
\text { anxiety }\end{array}$} & \multicolumn{4}{|c|}{ Univariable } & \multicolumn{4}{|c|}{ Multivariable } \\
\hline & & \multirow[t]{2}{*}{$\begin{array}{c}\text { Yes } \\
(n=245)\end{array}$} & \multirow[t]{2}{*}{$\begin{array}{c}\text { No } \\
(n=970)\end{array}$} & \multirow[t]{2}{*}{ OR } & \multirow[t]{2}{*}{$p$-Value } & \multicolumn{2}{|c|}{$\begin{array}{c}\text { Confidence Interval } \\
95 \%\end{array}$} & \multirow[t]{2}{*}{ AOR } & \multirow[t]{2}{*}{$p$-Value } & \multicolumn{2}{|c|}{$\begin{array}{c}\text { Confidence Interval } \\
95 \%\end{array}$} \\
\hline & & & & & & Lower & Upper & & & Lower & Upper \\
\hline Age (Median; Min-Max) & & $26(18-88)$ & $31(18-81)$ & - & $<0.001^{a}$ & - & - & 0,933 & $<0.001$ & 0.907 & 0.96 \\
\hline & Male (ref) & 45 & 286 & & & & & & & & \\
\hline \multirow[t]{2}{*}{ Educational level } & $\begin{array}{l}\text { Elementary/junior/senior } \\
\text { high school }\end{array}$ & 63 & 126 & 2.32 & $<0.001^{b}$ & 1.65 & 3.27 & 1.235 & 0.38 & 0.771 & 1.977 \\
\hline & $\begin{array}{l}\text { Bachelor/master/doctoral } \\
\text { (ref) }\end{array}$ & 182 & 844 & & & & & & & & \\
\hline Occupation & Health workers & 33 & 237 & & $<0.001^{b}$ & & & 0.209 & 0.013 & 0.061 & 0.721 \\
\hline Level of income & $\begin{array}{l}\text { Upper middle to high } \\
\text { income (ref) }\end{array}$ & 139 & 633 & & & & & & & & \\
\hline \multirow[t]{2}{*}{ Marital status } & Unmarried & 181 & 500 & 2.66 & $<0.001^{\mathrm{b}}$ & 1.95 & 3.63 & 1.128 & 0.568 & 0.747 & 1.702 \\
\hline & Married (ref) & 64 & 470 & & & & & & & & \\
\hline \multirow[t]{2}{*}{ Working from home } & Yes & 144 & 595 & 0.90 & $0.462^{\mathrm{b}}$ & 0.68 & 1.12 & - & & & \\
\hline & No (ref) & 101 & 375 & & & & & & & & \\
\hline \multirow[t]{2}{*}{ Practicing social restriction } & Yes & 236 & 945 & 0.69 & $0.353^{b}$ & 0.32 & 1.51 & - & & & \\
\hline & No (ref) & 9 & 25 & & & & & & & & \\
\hline Suspect case of COVID-19 & Yes & 22 & 61 & 1.47 & $0.136^{b}$ & 0.88 & 2.45 & 1.786 & 0.05 & 1.001 & 3.186 \\
\hline \multirow{2}{*}{$\begin{array}{l}\text { Behavior change due to } \\
\text { COVID-19 pandemic }\end{array}$} & Yes & 236 & 904 & 1.91 & $0.069^{b}$ & 0.94 & 3.90 & 1.993 & 0.085 & 0.91 & 4.365 \\
\hline & No (ref) & 9 & 66 & & & & & & & & \\
\hline \multirow{2}{*}{$\begin{array}{l}\text { Satisfaction level of family } \\
\text { support }\end{array}$} & Not satisfied & 57 & 49 & 5.70 & $<0.001^{\mathrm{b}}$ & 3.77 & 8.61 & 3.052 & 0 & 1.883 & 4.946 \\
\hline & Satisfied (ref) & 188 & 921 & & & & & & & & \\
\hline \multirow{2}{*}{$\begin{array}{l}\text { Satisfaction level of friends } \\
\text { support }\end{array}$} & Not satisfied & 43 & 40 & 4.95 & $<0.001^{b}$ & 3.14 & 7.81 & 1.373 & 0.362 & 0.694 & 2.718 \\
\hline & Satisfied (ref) & 202 & 930 & & & & & & & & \\
\hline Satisfaction level of & Not satisfied & 56 & 55 & 4.93 & $<0.001^{\mathrm{b}}$ & 3.29 & 7.38 & 2.523 & 0.002 & 1.395 & 4.562 \\
\hline & Satisfied (ref) & 189 & 915 & & & & & & & & \\
\hline
\end{tabular}

Constant: -3.381 ; Hosmer dan Lemeshow test: $\chi^{2}=14.631 . d f=8, p=0.067$; Nagelkerke $R^{2}=0.190$; ref, reference group.

aMann-Whitney test.

${ }^{b} \chi^{2}$ (chi-square).

age (12). Yet, more research regarding association between socioeconomic status and anxiety are needed.

Our findings on anxiety were higher when compared to several studies before the COVID-19 pandemic, including the national number from Indonesia Basic Health Research in 2018 which stated that $9.8 \%$ of the adult population had mental and emotional problems (18). Our proportion was also higher when compared to the WHO global prevalence of anxiety, which was $3.6 \%$ (29). When compared to other pandemics, such as SARS and MERS-CoV, in different countries, our proportion of anxiety 
prevalence was relatively higher. A meta-analysis performed by Rogers et al. (3) showed that the point prevalence of anxiety in the SARS outbreak was $14.8 \%$ (3). In addition, prevalence of anxiety among people in isolation (due to contact with positive cases) during the MERS outbreak in Korea was around $7.6 \%$ (30). However, the prevalence found in this study was relatively lower than the findings in countries like China and Turkey, which revealed anxiety prevalence of 35.1 and $45.1 \%$, respectively $(31,32)$. The wide gap might be explained by the variation in the timing of the study and the national situation of the COVID-19 pandemic.

Several factors have been identified to play a role in the increase of anxiety during the outbreak, as stated by the World Health Organization (WHO) (33). First, fear of being susceptible to infection was common during the outbreak (34). Second, misinterpretation of perceived bodily sensations and changes could lead to increased episodes of "health anxiety" or hypochondriasis (35). Third, excessive exposure to news related to COVID-19 and misinformation from untrustworthy sources could increase the level of anxiety (33). The news regarding COVID-19 is disseminated continuously through multiple media outlets such as newspapers, television, radio, and social media. People also tend to seek information related to the ongoing event to keep themselves updated, especially during times of crisis $(36,37)$. Yet, due to inadequate regulation of the information, people can be exposed to misleading information which results in acute stress and intense fear (36-38). Most of the respondents in the study stated that they had access to physical health information about COVID-19. However, only half of them gained mental health information regarding the disease. This provides insight into how many people perceive the current event as something that only affects their physical health. Furthermore, there was insufficient knowledge to support mental well-being during the pandemic due to limited information sources or reluctance to access the information provided. Therefore, special regulations must be made by the government to control the validity and reliability of information given in the media, along with the dissemination of mental health information on how to cope with the stressful circumstances of the pandemic (36-39).

This study also analyzed several factors that could be associated with anxiety level among the general population. Female gender was significantly associated with anxiety in this study. A study from Megatsari et al. (26) also found that young females experienced higher levels of anxiety compared to the male group. Females are known to have a higher risk of developing anxiety compared to males (40) due to both biological [e.g., sex chromosome $(41,42)$, reproductive hormone exposure (43)] and social factors (44). In addition, several studies about COVID-19 also reported that female gender was significantly related to anxiety (45-47). Over the last few years, most families have both the partners working. However, wives still share a larger responsibility of household chores and childcare (48). In this pandemic, the working from home policy might create a more intense burden for wives, as they need to fulfill their office obligations like attending meetings and completing tasks, at the same time as they need to accompany their children for activities like studying at home.

Marital status was found to be significantly associated with anxiety during the COVID-19 pandemic in the univariate analysis of this research. Unmarried (including single, widow, widower) status was found to increase the risk of anxiety in our study. These findings were in accordance with previous findings (49-51). As many have stated, marriage is commonly known as a protective situation against physical and mental health problems through several mediating factors, such as increased personal and social support, added social status, and stigma reduction (5254). However, in multivariate analysis, marital status was not significantly associated with anxiety. Our study did not evaluate the marital quality, which might be an important factor acting as a protective feature of marriage $(53,55)$.

Our findings also showed that lower educational level was significantly related to anxiety at the bivariate level, however it was found to not be significantly related at the multivariate level. This is different to what was shown in previous studies (56-58), although a study in the Indonesian population also found that respondents with secondary and lower education were around three times more likely to exhibit a higher level of anxiety (26). In our study, educational level was not related to anxiety due to the fact that this variable might be greatly influenced by other variables in our study, for example our study subjects were mostly health workers who showed a lower anxiety level in our study. Further study is thus recommended to evaluate educational level and anxiety symptoms during the COVID-19 pandemic in different populations. Several components, such as material, psychological, and behavioral factors, and the existence of chronic disease have been shown to play an important role in lower education related to anxiety (57). Material factors, such as housing tenure, no use of car, insufficient food budget, no private health insurance, and unemployment, were found to have strong connections with anxiety (57).

Our study showed that occupational status was not related to the occurrence of anxiety. However, multivariate analysis described that a healthcare worker was not more anxious than the unemployed. This might be associated with the amount of exposure to COVID-19-related information. They were confident in knowing and managing the symptoms, as well as in prevention practices. In contrast, the unemployed group may not have sufficient knowledge and skills to manage the risk due to lack of exposure $(39,59)$.

In our study, level of income, which could be included in the material factor, was not significantly related to anxiety in the multivariate analysis. This could be due to the fact that our survey was conducted during the initial period of the large-scale social restriction implementation; therefore, people still thought that the circumstance was only temporary. The huge economic loss had not been felt yet as the businesses had just been shut down for a short period (60). In spite of that, the higher economy class did not show a high prevalence of anxiety, because they might have been more prepared in case of financial problems if they caught COVID-19. 
In the present study, the majority of respondents were working from home and executing social restriction measurements. Anxiety may also have resulted from the impact of COVID-19 containment measures. Implementation of quarantine and social restriction policy leads to decreased social interaction which consequently increases loneliness. A study in China at the peak of the pandemic showed that home quarantine was part of the psychosocial stressors that were significantly associated with the development of anxiety and depression (8). Several studies have indicated that lonely individuals are more likely to have anxiety and depression as they do not have adequate social support $(37,39,61)$. People have been experiencing emotional exhaustion during this pandemic period and have been unable to unleash their emotions due to the isolation faced in the lockdown (39). It has also been reported that there is an increase in the number of people who experienced loneliness during this pandemic and it was significantly associated with suicidal ideation (62). Suicidal thoughts were found to be associated with level of confidence in controlling the pandemic, sufficient resources to survive during the pandemic, and adequacy of information received from the internet as well as from family (25).

Our study also showed that dissatisfaction toward support from family, friends, and co-workers was associated with anxiety. This observation is in line with the study conducted by $\mathrm{Ni}$ et al. (63) which showed the interrelation between social support and anxiety. Several studies have indicated that the increasing number of mental health cases worldwide may potentially develop into another pandemic (64). Certain groups of people were prone to mental health issues and had a lack of support; these included children, elderly, immunocompromised individuals, and healthcare providers. Particularly, parents commonly undermined their children's distress which led to anxiety (65). An Asian multi-countries study found that people with less satisfactory support had more suicidal thoughts among Indonesian students (25). Nonetheless, family support, especially among nuclear families, could improve during self-quarantine or social restriction. The enlargement of family support during quarantine happened as members shared their feelings more often and showed extensive care toward one another $(6,66)$. The family factor is expected to play a protective role toward anxiety, as strong bonds with family and the extended kinship network is a common practice in Indonesia. Family becomes the medium to establish intimate relationships in which the members could share feelings, solution to problems, respect, love, and care $(67,68)$. We presumed that social restriction policy was potentially weakening the social bond, yet nowadays, we can use digital information technology (IT) development as a part of a mitigation scheme to cope with mental health impact. Some popular communication platforms such as online video meetings and social media groups could help maintain mental health support. Healthcare providers extensively use this information technological advance to provide mental health information and telemedicine consultations $(63,64)$. However, it must be noted that anxiety can also be experienced by healthcare professionals. It is very important to plan special approaches to mitigate anxiety among healthcare workers, as they eventually play an enormous role in resolving anxiety in the community $(36,69)$.

The study also showed that younger age was related to clinically significant anxiety. This finding corresponds with several studies about COVID-19 and anxiety that showed that the younger population (especially young adults) tended to have more anxiety compared to their older counterparts $(12,26,67,70)$. This phenomenon could be explained by considering that young adults, in the majority, had to adapt to additional changes in their daily routine, including a new online educational or work environment (12). As they are currently in a transition period to becoming older adults, young adults also tend to worry about their future. Delay in academic learning has made college students feel anxious as they assume it may disturb their plan to pursue further academic study. The effect of the pandemic on income, job, or ability to pay loans have also become problems that young adults are concerned about; thus, it may trigger anxiety, especially in this pandemic which includes unstable economic circumstances (8). Furthermore, young adults also use social media more frequently when compared to the older population, which could induce anxiety due to information overload and misinformation (70). The elderly are assumed to be less anxious, are more resilient, and better at emotional management since they have more life experience compared to the youth (28).

This study also revealed that the health status of respondents was related to anxiety. However, data on the anxiety level of patients suspected to have COVID-19 were scarce. One study showed that prevalence of anxiety in suspected cases was not significantly different from the confirmed cases (71). On the contrary, another study showed that subjects suspected with COVID-19 could experience psychological distress due to uncertainty over disease status. Separation from family and loneliness along with negative stigmatization also became other issues during the quarantine period which could worsen psychological health $(72,73)$. Moreover, the majority of respondents in this research came from a higher education level. Better knowledge is associated with higher anxiety levels (74). In this case, the subjects might have better knowledge regarding COVID-19 risks that could trigger greater anxiety. In addition, health status of family members was found to be unrelated to anxiety. This finding resonated with several previous studies $(32,75,76)$. Anxiety might be influenced by several factors, thus further study is needed to obtain a clearer picture particularly in this pandemic circumstance.

This research provided important information that can help develop public policy for managing the COVID-19 pandemic or create a mitigation plan for a disaster/pandemic in the future. The high proportion of anxiety proves that it has been a crucial issue during the pandemic. Proper and continuous measures must be implemented to ensure optimum functioning of society, particularly within high-risk populations (young age, female, suspected case of COVID-19, and those with low quality of psychosocial support). To prevent mental health issues during and post-pandemic, people will need access to information and healthcare, availability 
of psychosocial support including social connectedness, and a supportive environment.

\section{CONCLUSION}

One in five people affected by the COVID-19 pandemic in Indonesia may have suffered from anxiety. Based on our findings, the factors associated with anxiety were younger age, female sex, suspected case of COVID-19, and less satisfying social support. Psychosocial support with the emphasis on accessible information and healthcare services, social connection, and a supportive environment in households as well as workplaces, are thought to be important. Nevertheless, health workers were found to have a lesser risk of developing anxiety. Further study on anxiety among people without access to digital technology and diverse age group populations (children, adolescents, and geriatrics) is suggested to fully understand the matter. Furthermore, surveillance regarding the long-term effects of the COVID-19 pandemic on mental health is also needed.

\section{DATA AVAILABILITY STATEMENT}

The raw data supporting the conclusions of this article will be made available by the authors, without undue reservation.

\section{REFERENCES}

1. Lu R, Zhao X, Li J, Niu P, Yang B, Wu H, et al. Genomic characterisation and epidemiology of 2019 novel coronavirus: implications for virus origins and receptor binding. Lancet. (2020) 395:565-74. doi: 10.1016/S0140-6736(20)30251-8

2. Desforges M, Le Coupanec A, Dubeau P, Bourgouin A, Lajoie L, Dubé M, et al. Human coronaviruses and other respiratory viruses: underestimated opportunistic pathogens of the central nervous system? Viruses. (2019) 12:14. doi: $10.3390 / \mathrm{v} 12010014$

3. Rogers JP, Chesney E, Oliver D, Pollak TA, McGuire P, Fusar-Poli $\mathrm{P}$, et al. Psychiatric and neuropsychiatric presentations associated with severe coronavirus infections: a systematic review and meta-analysis with comparison to the COVID-19 pandemic. Lancet Psychiatry. (2020) 7:611-27. doi: 10.1016/S2215-0366(20)30203-0

4. Directorate General of Disease Prevention and Control Ministry of Health of the Republic Indonesia. Prevention and Control Guideline of Coronavirus Disease (COVID-19). Jakarta (2020).

5. World Health Organization. Coronavirus disease 2019 (COVID-19) Situation Report-31. Vol. 31. Geneva (2020).

6. Zhang Y, Ma ZF. Impact of the COVID-19 pandemic on mental health and quality of life among local residents in Liaoning Province, China: a cross-sectional study. Int J Environ Res Public Health. (2020) 17:2381. doi: 10.3390/ijerph17072381

7. Dantzer R, Cohen S, Russo SJ, Dinan TG. Resilience and immunity. Brain Behav Immun. (2018) 74:28-42. doi: 10.1016/j.bbi.2018.08.010

8. Li J, Yang Z, Qiu H, Wang Y, Jian L, Ji J, et al. Anxiety and depression among general population in China at the peak of the COVID-19 epidemic. World Psychiatry. (2020) 19:249-50. doi: 10.1002/wps.20758

9. Kementerian Kesehatan Republik Indonesia. Pedoman Pembatasan Sosial Berskala Besar Dalam Rangka Percepatan Penanganan Corona Virus Disease 2019 (COVID-19). [Guidelines for Large-Scale Social Restrictions to Accelerate the Handling of Corona Virus Disease 2019 (COVID-19)]. Ministry of Health of Republic of Indonesia (2020). Available at: http://hukor.kemkes. go.id/uploads/produk_hukum/PMK_No_9_Th_2020_ttg_Pedoman_

\section{ETHICS STATEMENT}

The studies involving human participants were reviewed and approved by the Medical Research Ethics Committee from Faculty of Medicine Universitas Indonesia (KET375/UN2.F1/ETIK/PPM.00.02/2020). The patients/participants provided their written informed consent to participate in this study.

\section{AUTHOR CONTRIBUTIONS}

TW, GA, and HD were responsible for the study concept and design. TW, GA, HD, BM, NW, AP, EH, KM, and HC contributed to data or analysis tools. GA, BM, NW, AP, EH, KM, RI, $\mathrm{FK}$, and TW collected the data. GA, BM, HC, EH, and KM performed the data analysis. GA, BM, HC, EH, and $\mathrm{KM}$ wrote the manuscript. AS, CU, TW, and HD provided critical revision of the manuscript for intellectual content. All authors critically reviewed and approved the final version of the manuscript submitted for publication.

\section{ACKNOWLEDGMENTS}

We would like to thank all community members that willingly participated in this study.

Pembatasan_Sosial_Berskala_Besar_Dalam_Penanganan_COVID-19.pdf (accessed 24 Jan 2021).

10. Segrin C. APS Backgrounder Series: Psychological Science and COVID19: Social Impact on Adults. Association for Psychological Science (2020). Available online at: https://www.psychologicalscience.org/news/ backgrounders/covid-19-social-impacts-adults.html (accessed January 24, 2021).

11. Marsh JK, Shanks LL. Thinking you can catch mental illness: how beliefs about membership attainment and category structure influence interactions with mental health category members. Mem Cognit. (2014) 42:1011-25. doi: 10.3758/s13421-014-0 427-9

12. Ozamiz-etxebarria N, Dosil-santamaria M, Picaza-gorrochategui M, Idoiagamondragon N. Stress, anxiety, and depression levels in the initial stage of the COVID-19 outbreak in a population sample in the northern Spain Niveles de estrés, ansiedad y depresión en la primera fase del brote del COVID-19 en una muestra recogida en el norte de E. Cad Saúde Pública. (2020) 36:1-9. doi: 10.1590/0102-311x00054020

13. Rehman U, Shahnawaz MG, Khan NH, Kharshiing KD, Khursheed M, Gupta K, et al. Depression, anxiety and stress among Indians in times of COVID-19 lockdown. Community Ment Health J. (2021) 57:42-8. doi: 10.1007/s10597-020-00664-x

14. Sallam M, Dababseh D, Yaseen A, Al-Haidar A, Taim D, Eid H, et al. COVID19 misinformation: Mere harmless delusions or much more? A knowledge and attitude cross-sectional study among the general public residing in Jordan. PLoS ONE. (2020) 15:e0243264. doi: 10.1371/journal.pone.02 43264

15. Sommariva S, Vamos C, Mantzarlis A, Dao L, Tyson D. Spreading the (Fake) News: exploring health messages on social media and the implications for health professionals using a case study. Am J Heal Educ. (2018) 49:1-10. doi: 10.1080/19325037.2018.1473178

16. Amerongen DI, Cook LH. Mental illness: a modern-day leprosy? J Christ Nurs. (2010) 27:86-90. doi: 10.1097/CNJ.0b013e3181d26050

17. Chan AOM, Huak CY. Psychological impact of the 2003 severe acute respiratory syndrome outbreak on health care workers in a medium size 
regional general hospital in Singapore. Occup Med (Lond). (2004) 54:190-6. doi: 10.1093/occmed/kqh027

18. National Institute of Health Research and Development Ministry of Health of the Republic Indonesia. Indonesia Basic Health Research 2018. Jakarta (2019).

19. Reportal Data. Digital 2020 [Internet] (2020). Available online at: https:// datareportal.com/reports/digital-2020-indonesia (accessed January 25, 2021).

20. Britannica T. Nuclear family. In: Encyclopedia Britannica (2015). Available online at: https://www.britannica.com/topic/nuclear-family (accessed February 24, 2021).

21. Spitzer RL, Kroenke K, Williams JBW, Löwe B. A brief measure for assessing generalized anxiety disorder: the GAD-7. Arch Intern Med. (2006) 166:1092-7. doi: 10.1001/archinte.166.10.1092

22. Budikayanti A, Larasari A, Malik K, Syeban Z, Indrawati LA, Octaviana F. Screening of generalized anxiety disorder in patients with epilepsy: using a valid and reliable Indonesian version of generalized anxiety disorder7 (GAD-7). Di Lazzaro V, editor. Neurol Res Int. (2019) 2019:5902610. doi: 10.1155/2019/5902610

23. Plummer F, Manea L, Trepel D, McMillan D. Screening for anxiety disorders with the GAD-7 and GAD-2: a systematic review and diagnostic metaanalysis. Gen Hosp Psychiatry. (2016) 39:24-31. doi: 10.1016/j.genhosppsych.2015.11.005

24. Statistika BP. Penduduk Berumur 15 Tahun Ke Atas Menurut Pendidikan Tertinggi yang Ditamatkan dan Jenis Kegiatan Selama Seminggu yang Lalu, 2008-2020 [Internet] (2020). Available online at: https://www.bps. go.id/statictable/2016/04/05/1909/penduduk-berumur-15-tahun-ke-atasmenurut-pendidikan-tertinggi-yang-ditamatkan-dan-jenis-kegiatanselama-seminggu-yang-lalu-2008-2020.html (accessed January 25, 2021).

25. Pramukti I, Strong C, Sitthimongkol Y, Setiawan A, Pandin MGR, Yen C-F, et al. Anxiety and suicidal thoughts during the COVID-19 pandemic: cross-country comparative study among Indonesian, Taiwanese, and Thai University students. J Med Internet Res. (2020) 22:e24487. doi: 10.2196/24487

26. Megatsari H, Laksono AD, Ibad M, Herwanto YT, Sarweni KP, Geno RAP, et al. The community psychosocial burden during the COVID-19 pandemic in Indonesia. Heliyon. (2020) 6:e05136. doi: 10.1016/j.heliyon.2020.e05136

27. Statistika BP. Statistik Indonesia 2020 : Statistical Yearbook of Indonesia 2020. Jakarta (2020).

28. Solomou I, Constantinidou F. Prevalence and predictors of anxiety and depression symptoms during the COVID-19 pandemic and compliance with precautionary measures: age and sex matter. Int J Environ Res Public Health. (2020) 17:4924. Available online at: doi: 10.3390/ijerph17144924

29. World Health Organization. Depression and Other Common Mental Disorders Global Health Estimates. Geneva (2017).

30. Jeong H, Yim HW, Song Y-J, Ki M, Min J-A, Cho J, et al. Mental health status of people isolated due to Middle East Respiratory Syndrome. Epidemiol Health. (2016) 38:e2016048. doi: 10.4178/epih.e2016048

31. Huang Y, Zhao N. Generalized anxiety disorder, depressive symptoms and sleep quality during COVID-19 outbreak in China: a webbased cross-sectional survey. Psychiatry Res. (2020) 288:112954. doi: 10.1016/j.psychres.2020.112954

32. Özdin S, Bayrak Özdin S. Levels and predictors of anxiety, depression and health anxiety during COVID-19 pandemic in Turkish society: the importance of gender. Int J Soc Psychiatry. (2020) 0020764020927051. doi: $10.1177 / 0020764020927051$

33. World Health Organization. Mental Health and Psychosocial Considerations During the COVID-19 Outbreak. Geneva (2020).

34. Fardin MA. COVID-19 and anxiety: a review of psychological impacts of infectious disease outbreaks. Arch Clin Infect Dis. (2020) 15:e102779. doi: 10.5812/archcid.102779

35. Rajkumar RP. COVID-19 and mental health: a review of the existing literature. Asian J Psychiatr. (2020) 52:102066. doi: 10.1016/j.ajp.2020.102066

36. Torales J, O'Higgins M, Castaldelli-Maia JM, Ventriglio A. The outbreak of COVID-19 coronavirus and its impact on global mental health. Int J Soc Psychiatry. (2020) 66:317-20. doi: 10.1177/0020764020915212

37. Jung SJ, Jun JY. Mental health and psychological intervention amid COVID19 outbreak: Perspectives from South Korea. Yonsei Med J. (2020) 61:271-2. doi: $10.3349 /$ ymj.2020.61.4.271

38. Banerjee D. The COVID-19 outbreak: Crucial role the psychiatrists can play. Asian J Psychiatr. (2020) 50:102014. doi: 10.1016/j.ajp.2020.102014
39. Roy D, Tripathy S, Kar SK, Sharma N, Verma SK, Kaushal V. Study of knowledge, attitude, anxiety \& perceived mental healthcare need in Indian population during COVID-19 pandemic. Asian J Psychiatr. (2020) 51:102083. doi: 10.1016/j.ajp.2020.102083

40. Mclean CP, Asnaani A, Litz BT, Hofmann SG. Gender differences in anxiety disorders : Prevalence, course of illness, comorbidity and burden of illness. $J$ Psychiatr Res. (2011) 45:1027-35. doi: 10.1016/j.jpsychires.2011.03.006

41. Seney ML, Ekong KI, Ding Y, Tseng GC, Sibille E. Sex chromosome complement regulates expression of mood-related genes. Biol Sex Differ. (2013) 4:20. doi: 10.1186/2042-6410-4-20

42. Green T, Flash S, Reiss AL. Sex differences in psychiatric disorders : what we can learn from sex chromosome aneuploidies. Neuropsychopharmacology. (2019) 44:9-21. doi: 10.1038/s41386-018-0153-2

43. McCarthy MM, Arnold AP, Ball GF, Blaustein JD, De Vries GJ. Sex differences in the brain: the not so inconvenient truth. J Neurosci. (2012) 32:2241-7. doi: 10.1523/JNEUROSCI.5372-11.2012

44. Altemus M, Sarvaiya N, Neill Epperson C. Sex differences in anxiety and depression clinical perspectives. Front Neuroendocrinol. (2014) 35:320-30. doi: 10.1016/j.yfrne.2014.05.004

45. Lai J, Ma S, Wang Y, Cai Z, Hu J, Wei N, et al. Factors associated with mental health outcomes among health care workers exposed to coronavirus disease 2019. JAMA Netw Open. (2020) 3:e203976. doi: 10.1001/jamanetworkopen.2020.3976

46. Lei L, Huang $\mathrm{X}$, Zhang S, Yang J, Yang L, Xu M. Comparison of prevalence and associated factors of anxiety and depression among people affected by vs. people unaffected by quarantine during the COVID19 epidemic in Southwestern China. Med Sci Monit. (2020) 26:e924609. doi: 10.12659/MSM.924609

47. Wang C, Pan R, Wan X, Tan Y, Xu L, Ho CS, et al. Immediate psychological responses and associated factors during the initial stage of the 2019 coronavirus disease (COVID-19) epidemic among the general population in China. Int J Environ Res Public Health. (2020) 17:1729. doi: $10.3390 /$ ijerph 17051729

48. Utomo AJ. Gender in the midst of reforms: attitudes to work and family roles among university students in urban Indonesia. Marriage Fam Rev. (2016) 52:421-41. doi: 10.1080/01494929.2015.1113224

49. Scott KM, Wells JE, Angermeyer M, Brugha TS, Bromet E, Demyttenaere K, et al. Gender and the relationship between marital status and first onset of mood, anxiety and substance use disorders. Psychol Med. (2009) 40:1495-505. doi: 10.1017/S0033291709991942

50. Williams BR, Sawyer P, Roseman JM, Allman RM. Marital status and health: exploring pre-widowhood. J Palliat Med. (2008) 11:848-56. doi: 10.1089/jpm.2007.0190

51. Onrust SA, Cuijpers P. Mood and anxiety disorders in widowhood: a systematic review. Aging Ment Health. (2006) 10:327-34. doi: $10.1080 / 13607860600638529$

52. Willitts M, Benzeval M, Stansfeld S. Partnership history and mental health over time. J Epidemiol Community Health. (2004) 58:53-8. doi: 10.1136/jech.58.1.53

53. Robles TF, Slatcher RB, Trombello JM, McGinn MM. Marital quality and health: a meta-analytic review. Psychol Bull. (2013) 140:140-87. doi: $10.1037 / \mathrm{a} 0031859$

54. Srivastava A. Marriage as a perceived panacea to mental illness in India: Reality check. Indian J Psychiatry. (2013) 55(Suppl. 2):S239-42. doi: 10.4103/0019-5545.105542

55. Robles TF. Marital quality and health: implications for marriage in the 21(st) century. Curr Dir Psychol Sci. (2014) 23:427-32. doi: $10.1177 / 0963721414549043$

56. Thurston RC, Kubzansky LD, Kawachi I, Berkman LF. Do depression and anxiety mediate the link between educational attainment and CHD? Psychosom Med. (2006) 68:25-32. doi: 10.1097/01.psy.0000195883.68888.68

57. Chazelle E, Lemogne C, Morgan K, Kelleher CC, Chastang J-F, Niedhammer I. Explanations of educational differences in major depression and generalised anxiety disorder in the Irish population. J Affect Disord. (2011) 134:304-14. doi: 10.1016/j.jad.2011.05.049

58. Bjelland I, Krokstad S, Mykletun A, Dahl AA, Tell GS, Tambs K. Does a higher educational level protect against anxiety and depression? The HUNT study. Soc Sci Med. (2008) 66:1334-45. doi: 10.1016/j.socscimed.2007.12.019 
59. Shah SMA, Mohammad D, Qureshi MFH, Abbas MZ, Aleem S. Prevalence, Psychological Responses and associated correlates of depression, anxiety and stress in a global population, during the coronavirus disease (COVID-19) pandemic. Community Ment Health J. (2020) 57:101-10. doi: 10.1007/s10597-020-00728-y

60. Susilawati, Falefi R, Purwoko A. Impact of COVID-19's Pandemic on the economy of Indonesia. Budapest Int Res Critics Institute-Journal. (2020) 3:1147-56. doi: 10.33258/birci.v3i2.954

61. Baytemir K, Yildiz MA. Multiple mediation of loneliness and negative emotions in the relationship between adolescents' social anxiety and depressive symptoms. An Psicol. (2017) 33:612. doi: 10.6018/analesps.33.3.269211

62. Killgore WDS, Cloonan SA, Taylor EC, Dailey NS. Loneliness: a signature mental health concern in the era of COVID-19. Psychiatry Res. (2020) 290:113117. doi: 10.1016/j.psychres.2020.113117

63. Ni MY, Yang L, Leung CMC, Li N, Yao XI, Wang Y, et al. Mental health, risk factors, and social media use during the COVID-19 epidemic and cordon sanitaire among the community and health professionals in Wuhan, China: cross-sectional survey. JMIR Ment Heal. (2020) 7:e19009. doi: 10.2196/19009

64. Ornell F, Schuch JB, Sordi AO, Kessler FHP. "Pandemic fear" and COVID19: mental health burden and strategies. Rev Bras Psiquiatr. (2020) 42:232-5. doi: 10.1590/1516-4446-2020-0008

65. Koven S. They Call Us and We Go. N Engl J Med. (2020) 382:1978-9. doi: 10.1056/NEJMp2009027

66. El-Zoghby SM, Soltan EM, Salama HM. Impact of the COVID-19 pandemic on mental health and social support among adult Egyptians. J Community Health. (2020) (0123456789). doi: 10.1007/s10900-020-00853-5

67. Qibthiyyah R, Utomo AJ. Family Matters: Demographic Change and Social Spending in Indonesia. Bull Indones Econ Stud [Internet]. (2016) 52:133-59. doi: 10.1080/00074918.2016.1211077

68. Herawati T, Kumalasari B, Musthofa M, Tyas FPS. Dukungan Sosial, Interaksi Keluarga, dan Kualitas Perkawinan pada Keluarga Suami Istri Bekerja. J Ilmu Kel dan Konsum. (2018) 11:1-12. doi: 10.24156/jikk.2018.11.1.1

69. Shanafelt T, Ripp J, Trockel M. Understanding and addressing sources of anxiety among health care professionals during the COVID-19 pandemic. JAMA. (2020) 323:2133-4. doi: 10.1001/jama.2020.5893

70. Gao J, Zheng P, Jia Y, Chen H, Mao Y, Chen S, et al. Mental health problems and social media exposure during COVID-19 outbreak. PLoS ONE. (2020) 15:e0231924. doi: 10.1371/journal.pone.0231924
71. Paz C, Mascialino G, Adana-Díaz L, Rodríguez-Lorenzana A, Simbaña-Rivera K, Gómez-Barreno L, et al. Anxiety and depression in patients with confirmed and suspected COVID-19 in Ecuador. Psychiatry Clin Neurosci. (2020) 74:554-5. doi: 10.1111/pc n.13106

72. Upadhyay R, Sweta, Singh B, Singh U. Psychological impact of quarantine period on asymptomatic individuals with COVID-19. Soc Sci Humanit Open. (2020) 2:100061. doi: 10.1016/j.ssaho.2020.1 00061

73. Benke C, Autenrieth LK, Asselmann E, Pané-Farré CA. Lockdown, quarantine measures, and social distancing: associations with depression, anxiety and distress at the beginning of the COVID-19 pandemic among adults from Germany. Psychiatry Res. (2020) 293:113462. doi: 10.1016/j.psychres.2020.113462

74. Selinger CP, Lal S, Eaden J, Jones DB, Katelaris P, Chapman G, et al. Better disease specific patient knowledge is associated with greater anxiety in inflammatory bowel disease. J Crohn's Colitis. (2013) 7:e214-8. doi: 10.1016/j.crohns.2012.09.014

75. Li G, Miao J, Wang H, Xu S, Sun W, Fan Y, et al. Psychological impact on women health workers involved in COVID-19 outbreak in Wuhan: a cross-sectional study. J Neurol Neurosurg Psychiatry. (2020) 91:895-7. doi: 10.1136/jnnp-2020-323134

76. Kong X, Zheng K, Tang M, Kong F, Zhou J, Diao L, et al. Prevalence and factors associated with depression and anxiety of hospitalized patients with COVID-19. medRxiv [preprint]. (2020). doi: 10.1101/2020.03.24. 20043075

Conflict of Interest: The authors declare that the research was conducted in the absence of any commercial or financial relationships that could be construed as a potential conflict of interest.

Copyright (c) 2021 Anindyajati, Wiguna, Murtani, Christian, Wigantara, Putra, Hanafi, Minayati, Ismail, Kaligis, Savitri, Uiterwaal and Diatri. This is an openaccess article distributed under the terms of the Creative Commons Attribution License (CC BY). The use, distribution or reproduction in other forums is permitted, provided the original author(s) and the copyright owner(s) are credited and that the original publication in this journal is cited, in accordance with accepted academic practice. No use, distribution or reproduction is permitted which does not comply with these terms. 